\title{
Neural Induction of Taste Buds
}

\author{
MARK A. HOSLEY, STEPHEN E. HUGHES, AND BRUCE OAKLEY \\ Department of Biology, Neuroscience Laboratory Building, University of Michigan,
} Ann Arbor, Michigan 48109

\begin{abstract}
Bilateral innervation allows more than $80 \%$ of the 610 vallate taste buds to survive removal of one IXth nerve in adult rats. Removal of both IXth nerves in neonatal or adult rats results in the absence of taste buds. In studying development, we found that removing or crushing one IXth nerve in three-day-old neonates profoundly decreased the number of vallate taste buds that subsequently developed. Specifically, after removal of one IXth nerve at 3 days, only 228 taste buds formed, compared with 496 taste buds that one nerve would maintain in adults. Thus, during normal development, the right and left IXth nerves interact synergistically, as at least 150 more taste buds develop than predicted by the sum of the independent action of each IXth nerve. This suggests that vallate taste buds are induced by the IXth nerve. A second example of synergism, representing evidence for the neural induction of taste buds, came from experiments in which we crushed the left IXth nerve 3 days after birth and found that these regenerated IXth nerve axons induced 4 times as many taste buds in the presence of the normal right IXth nerve (118 taste buds) as in its early absence (30 taste buds).

We conclude that taste buds are neurally induced and that axons of the IXth nerve interact synergistically in inducing them, rather than competing for targets. We propose that in development innervated progenitor cells form stem cells which lead to taste bud cells.
\end{abstract}

Key words: competition, development, regeneration, stem cells, synergism, IXth nerve

The role of axons in the development of sensory receptors has been examined primarily for the Pacinian corpuscle and muscle spindle. Denervation in the first postnatal week prevents formation of rat muscle spindles (Zelena, '57; Werner, '73; Zelena and Soukup, '73; Schiaffino and Pierobon, '76). In adult rats, muscle spindles will regenerate in the absence of innervation if their capsules have remained intact (Rogers, '81; Rogers and Carlson, '81). Thus, although there is an apparent inductive role for the nerve supply in muscle spindle formation, there is no clear neurotrophic requirement for spindle maintenance and regeneration in adults. For Pacinian corpuscles, denervation by $4 \mathrm{~d}$ causes degeneration of the immature corpuscle. Since there is no effect of denervation after $9 \mathrm{~d}$, it is clear that the adult Pacinian corpuscle is not neurotrophically maintained (Zelena et al., '78; Zelena, '80). Thus, muscle spindles and Pacinian corpuscles appear to be neurally induced in development, but are not neurotrophically maintained in adults.

A century ago Hermann (1884) speculated that innervation was required for the development of taste buds. Hermann's conjecture has been reiterated in several subsequent studies of taste bud development (e.g., Torrey, '40; Farbman, '72). Although the temporal correlation between the arrival of nerve fibers and the subsequent appearance of taste buds is suggestive, it is not conclusive. Harrison ('04), for example, believed that the invasion of the taste papillae by axons and the formation of taste buds were merely coincidental. In his view the nerve acted trophically to maintain taste buds that had already developed by their inherent capacity to differentiate. As State and Bowden (74) have said, "Direct experimental evidence must be forthcoming if the concept of neural induction of taste buds

Accepted December 2, 1986

Send reprint requests to Bruce Oakley, Neuroscience Lab. Bldg., University of Michigan, Ann Arbor, MI 48109.

M.A. Hosley's present address is Brown University Medical School, Providence, RI 02912.

S.E. Hughes's present address is Central Institute for the Deaf and Department of Speech and Hearing, Washington University, St. Louis, MO 63110. 
is to receive general acceptance" (p. 220). Previous experimental studies on taste bud development have focused on transplanting portions of the fetal tongue into either an in vitro culture system (Farbman, '72) or the anterior chamber of the eye (Torrey, '40; Zalewski, '74). However, the shortages of developing taste buds observed in these studies may have resulted from the effects of trauma or an abnormal environment rather than from a lack of taste axons.

We sought to test whether innervation is necessary by attempting in situ denervation of the taste papilla prior to the normal formation of taste buds. We hypothesized that for taste buds, as for muscle spindles and Pacinian corpuscles, early in situ denervation would prevent receptor development and differentiation. To test this hypothesis, we selected the circumvallate papilla because it is a compact structure containing more than 600 taste buds that mature after birth (Hosley and Oakley, '87). Denervation can be carried out at $3 \mathrm{~d}$ before $97 \%$ of the taste buds have matured to see if taste buds can develop independently of a nerve supply. Only the IXth (glossopharyngeal) nerve innervates the papilla. In adult rats, the majority of vallate taste buds are bilaterally innervated (Whiteside, '27; Guth, '63; Oakley, '74). Thus, at a series of sacrifice ages from $5 \mathrm{~d}$ through $90 \mathrm{~d}$, we evaluated the effects of interrupting one or both IXth nerves on the total number of vallate taste buds formed and on the morphology of the papilla.

\section{MATERIALS AND METHODS}

Sprague-Dawley rats (Rattus norvegicus) were used to study the effects of early interruption of the IXth (glossopharyngeal) nerve supply to the circumvallate papilla. Anesthesia was induced with ether masks for $3 \mathrm{~d}$ pups or with sodium pentobarbital i.p., $5 \mathrm{mg} / \mathrm{kg}$, combined with ketamine-HC1 i.m., $125 \mathrm{mg} / \mathrm{kg}$, for adults. Adults also received a 50,000 unit $/ \mathrm{kg}$ i.m. injection of Bicillin antibiotic 12-24 hours prior to surgery. Nerve avulsion consisted of removing the IXth nerve between the petrosal ganglion and the tongue with number five watchmaker's forceps. Nerve crushes were made just proximal to the pharyngeal branch of the IXth nerve by pinching the nerve 10-25 times with the tips of number five watchmaker's forceps, followed by visual inspection to verify that the nerve was not transected. Ninety days postpartum was generally the oldest sacrifice age since $0-180 \mathrm{~d}$ normal animals had maximal numbers of taste buds by $90 \mathrm{~d}$ (Hosley and Oakley, ' 87 ). We examined 7 control groups and 5 experimental groups that underwent operations on the IXth nerve (right IXth nerve/ left IXth nerve):

\section{Control}

Two control groups of sham nerve-operated animals were used in which the right IXth nerve was exposed without manipulation at either $3 \mathrm{~d}$ in the first group or $75 \mathrm{~d}$ in the second group.

1. (SH3/NORM) The animals were sacrificed at ages 5 through $90 \mathrm{~d}, \mathrm{~N}=48$.

2. (SH75/NORM) The animals were sacrificed at $90 \mathrm{~d}$, $\mathrm{N}=6$.

3. (AV75/NORM) The right IXth nerve was avulsed at 75 $\mathrm{d}$ and the animals sacrificed either 15 or $21 \mathrm{~d}$ postoperatively. Since there were no significant differences between the two sacrifice ages, the data were pooled, $\mathrm{N}=11$.

4. (AV75/AV75) Both IXth nerves were avulsed at $75 \mathrm{~d}$ and the rats sacrificed $15 \mathrm{~d}$ postoperatively at $90 \mathrm{~d}$, $\mathrm{N}=4$.
5. (AV75/CR75) The right IXth nerve was avulsed and the left crushed at $75 \mathrm{~d}$ and the animals sacrificed at $150 \mathrm{~d}, \mathrm{~N}$ $=7$.

6. (AV3/AV3) Both IXth nerves were avulsed at $3 \mathrm{~d}$, four animals were sacrificed at $10 \mathrm{~d}$, and four at $90 \mathrm{~d}, \mathrm{~N}=8$.

7. (AV3/AV75) After avulsion of the right IXth nerve at 3 $d$, this group underwent a second operation at $75 \mathrm{~d}$ in which the remaining left IXth nerve was avulsed and the animals were sacrificed $15 \mathrm{~d}$ postoperatively, at $90 \mathrm{~d}, \mathrm{~N}=7$. This was done to determine whether axons of the right IXth nerve had survived and reinnervated the papilla.

\section{Experimental}

1. (AV3/NORM) After avulsion of the right IXth nerve at $3 \mathrm{~d}$ the animals were sacrificed at ages 5 through $90 \mathrm{~d}$, $\mathrm{N}=75$.

2. (AV3/CR3) The right IXth nerve was avulsed and the left crushed at $3 \mathrm{~d}$ and the animals sacrificed at $10 \mathrm{~d}(\mathrm{~N}=$ $5), 15 \mathrm{~d}(\mathrm{~N}=5), 18 \mathrm{~d}(\mathrm{~N}=4), 45 \mathrm{~d}(\mathrm{~N}=5), 60 \mathrm{~d}(\mathrm{~N}=7)$, and $90 \mathrm{~d}(\mathrm{~N}=7)$.

In the following experiments the right IXth nerve was unilaterally crushed at $3 \mathrm{~d}$ to create an early period of temporary denervation. These animals were divided into three subgroups:

3a. (CR3/NORM) These animals were sacrificed at 15 through $90 \mathrm{~d}, \mathrm{~N}=47$.

3b. (CR3+AV75/NORM) These animals underwent surgery at $75 \mathrm{~d}$ to remove the crushed right nerve and were sacrificed $15 \mathrm{~d}$ postoperatively, at $90 \mathrm{~d}, \mathrm{~N}=8$. This surgery was performed to determine the number of taste buds maintained by the normal left nerve.

3c. (CR3/AV75) The third subgroup had the normal left IXth nerve avulsed at $75 \mathrm{~d}$. The animals were sacrificed 15 d postoperatively at $90 \mathrm{~d}, \mathrm{~N}=7$. This determined how many taste buds were maintained by the right nerve, which had been crushed at $3 \mathrm{~d}$.

Young animals, aged $10 \mathrm{~d}$ or less, were sacrificed by cervical dislocation, while older animals were sacrificed with an overdose of sodium pentobarbital. The vallate papilla was excised, fixed in a solution of $10 \%$ formalin, $15 \%$ sucrose, and $1 \% \mathrm{NH}_{4} \mathrm{OH}$, embedded in paraffin, serially cross-sectioned at $10 \mu \mathrm{m}$ and stained in Heidenhain's ironhematoxylin to accentuate the taste pore (Guth, '57). 'To reduce the chance of counting an individual taste bud more than once, taste bud counts were based on the presence of a taste pore, of which there was one per mature taste bud. By definition, there is no taste pore in an immature taste bud. Except for some taste buds at the rostrocaudal extremes of the papilla, cross sections provide a favorable plane for viewing the taste pore.

The length of the papilla's centrum (elliptical central mound) was determined from the number of $10 \mu \mathrm{m}$ sections displaying the papilla and its trench walls. Measurements on three cross sections at the midlength of the papilla provided averages for centrum width, trench depth, and maximal thickness of trench wall epidermis.

We sacrificed 3 NORM/NORM, 3 AV3/NORM, and 3 AV3/ CR3 animals at $90 \mathrm{~d}$ and removed a short segment of the IXth nerve distal to its exit from the posterior lacerated foramen and proximal to the pharyngeal branch. In the case of previously crushed nerves, the segment removed was proximal to the site of nerve crush. We embedded the nerve segments in plastic, according to the protocol of Hughes et al. ('83). Plastic sections, 0.5-2.0 $\mu \mathrm{m}$ thick, were stained with paragon (Spurlock et al., '66), and light micro- 
graphs were used to count the total number of myelinated axon profiles present in each nerve. This method of counting myelinated axons was found by Berthold and Carlstedt (73) to give values $99 \%$ in agreement with counts made from electron micrographs.

Statistical analyses were performed using the MIDAS statistical program at the University of Michigan computer facilities. The statistical analyses included regression analysis of the linearized results in which the dependent variables were plotted as a function of log sacrifice age (Dowdy and Wearden, '83). Comparisons were then made to test for differences of both the slope and intercepts between the NORM/NORM, SH3/NORM, AV3/NORM, and CR3/NORM groups, for which data had been collected at a variety of ages. When means were compared between multiple groups at only one sacrifice age, pair-wise comparisons were made by ANOVA to determine which surgical groups differed significantly from one another. For comparisons between means of selected pairs, Student's t-test was used. Only probability values of $<0.01$ have been considered statistically significant.

\section{RESULTS}

A mature vallate taste bud consists of a pear-shaped aggregation of fusiform cells whose nuclei lie deep to the narrow taste pore that allows taste solutions to bathe the tips of the receptor cells in the taste pit (Fig. 1E). Vallate taste buds develop postnatally, progressively rising in number from zero at birth to an average of 125 taste buds at 10 $d$ and 610 at $90 \mathrm{~d}$ (Table 1; described in detail in Hosley and Oakley, ' 87 ). In contrast, no vallate taste buds were present at $10 \mathrm{~d}$ in any of 4 animals in which the IXth nerve had been bilaterally avulsed at $3 \mathrm{~d}(\mathrm{AV} 3 / \mathrm{AV} 3=0$ at $10 \mathrm{~d}$; Table 1). Nor were there vallate taste buds in any of the 14 animals examined 10,15 , or $18 \mathrm{~d}$ postpartum after avulsion of the right IXth nerve and crush of the left IXth nerve at $3 \mathrm{~d}(\mathrm{AV} 3 / \mathrm{CR} 3=0$ at 10, 15, and $18 \mathrm{~d}$; Table 1). At $90 \mathrm{~d}, 6$ of 7 animals had no vallate taste buds, and 1 had 12 buds following avulsion of the right IXth nerve at $3 \mathrm{~d}$ and the left IXth nerve at $75 \mathrm{~d}(\mathrm{AV} 3 / \mathrm{AV} 75=1.7 \pm 4.5 ;$ mean \pm 1 S.D.). After avulsion of both IXth nerves at $3 \mathrm{~d}$ (AV3/AV3), a mean of $16 \pm 25$ vallate taste buds (Table 1 ) were present at $90 \mathrm{~d}(0,2,8$, and 52 taste buds in 4 animals). Successful
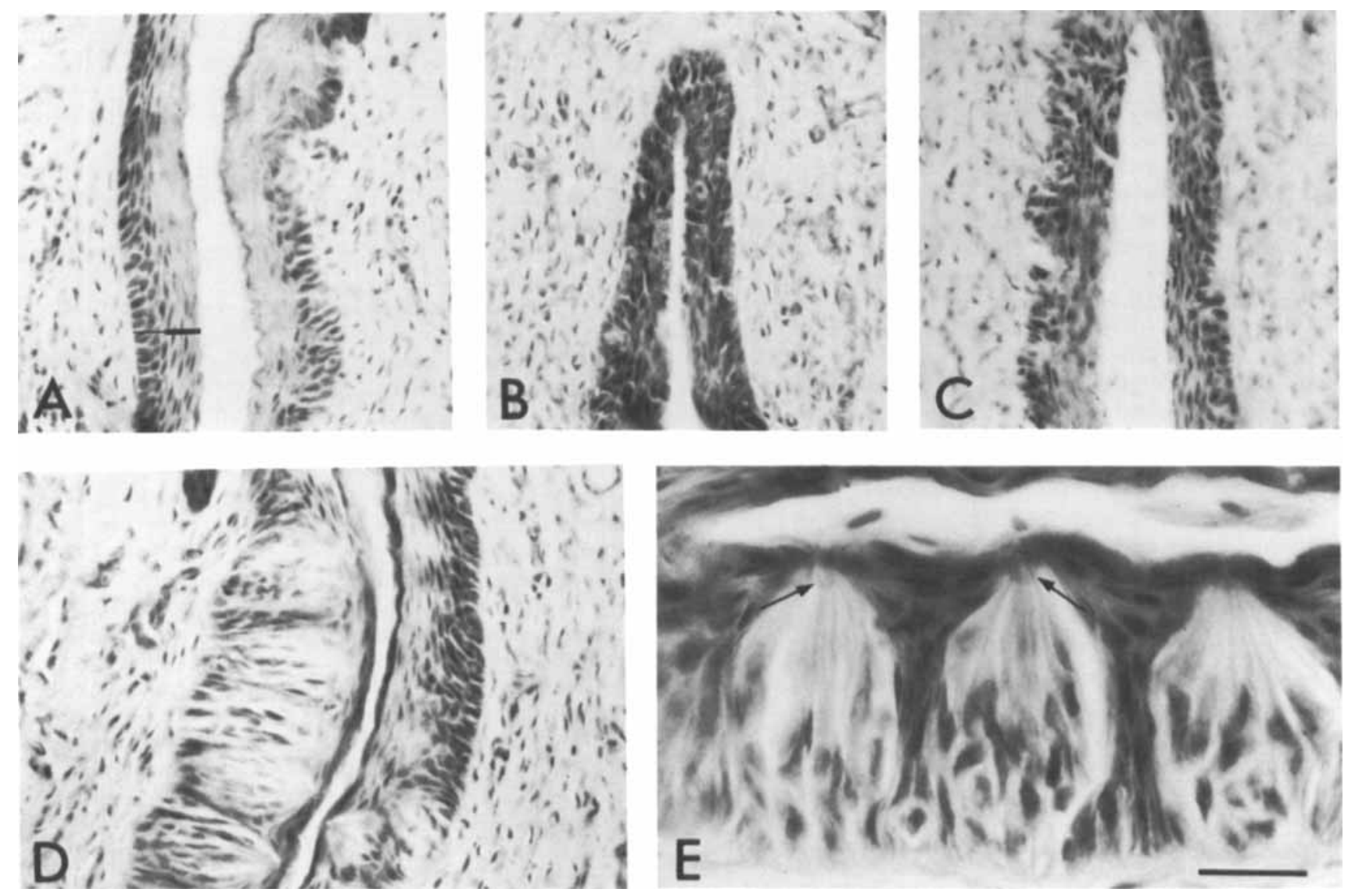

Fig. 1. Trench wall and taste buds of the rat vallate papilla. A. AV3/AV3 at $90 \mathrm{~d}$. The superficial squamous layers (thick bar) and the deeper germinal laver (thin bar) are evident. Taste buds are absent. B. AV3/CR3 at $90 \mathrm{~d}$. In this area of the vallate papilla, as in most regions of its trench wall epidermis, there were no taste buds. C. AV75/AV75 at 90 d. There were no intact taste buds, but remnants of degenerated taste buds still distort the normal

appearance of the denervated epithelium. D. AV3/CR3. Five taste buds are clustered together on the outer left trench wall, which is thicker than the inner wall that nearly lacks taste buds. E. Three mature vallate taste buds of a normal animal at $90 \mathrm{~d}$. The arrows indicate the more darkly stained regions of the taste pit/pore. The scale line in $\mathrm{E}$ is $70 \mu \mathrm{m}$ for $\mathrm{A}-\mathrm{D}, 25 \mu \mathrm{m}$ for E. 
TABLE I. Number of Mature Vallate Taste Buds ${ }^{1}$

\begin{tabular}{|c|c|c|c|c|c|c|c|c|c|c|c|c|c|}
\hline & \multicolumn{13}{|c|}{ Sacrifice age (days postpartum) } \\
\hline & 0 & 1 & 3 & 5 & 10 & 15 & 21 & 33 & 45 & 60 & 90 & 120 & 180 \\
\hline NORM/NORM & $\begin{array}{l}0.3 \\
\pm 0.49\end{array}$ & $\begin{array}{l}0.8 \\
\pm 1.30\end{array}$ & $\begin{array}{l}17.0 \\
\pm 18.7\end{array}$ & $\begin{array}{l}21.3 \\
\pm 20.6\end{array}$ & $\begin{array}{l}124.6 \\
\pm 40.4\end{array}$ & $\begin{array}{l}152.8 \\
\pm 25.2\end{array}$ & $\begin{array}{l}266.6 \\
\pm 49.1\end{array}$ & $\begin{array}{l}404.1 \\
\pm 85.8\end{array}$ & $\begin{array}{l}460.1 \\
\pm 74.1\end{array}$ & $\begin{array}{l}546.5 \\
\pm 111.1\end{array}$ & $\begin{array}{l}610.0 \\
+87.0\end{array}$ & $\begin{array}{l}598.3 \\
\pm 132.5\end{array}$ & $\begin{array}{l}573.0 \\
\pm 63.3\end{array}$ \\
\hline SH3/NORM & & & & $\begin{array}{l}74.2 \\
\pm 30.8\end{array}$ & $\begin{array}{l}97.8 \\
\pm 30.5\end{array}$ & $\begin{array}{l}166.6 \\
\pm 93.4\end{array}$ & $\begin{array}{l}295.8 \\
\pm 81.7\end{array}$ & $\begin{array}{l}398.6 \\
\pm 55.9\end{array}$ & $\begin{array}{l}354.2 \\
\pm 40.3\end{array}$ & $\begin{array}{l}653.2 \\
\pm 119.3\end{array}$ & $\begin{array}{l}585.8 \\
\pm 91.3\end{array}$ & & \\
\hline AV3/AV3 & & & & & $\begin{array}{l}0.0 \\
\pm 0.0\end{array}$ & & & & & & $\begin{array}{l}\mathbf{1 5 . 5} \\
\pm 24.6\end{array}$ & & \\
\hline AV75/AV75 & & & & & & & & & & & $\begin{array}{l}0.0 \\
\pm 0.0\end{array}$ & & \\
\hline AV3/CR3 & & & & & $\begin{array}{l}0.0 \\
\pm 0.0\end{array}$ & $\begin{array}{l}0.0 \\
\pm 0.0\end{array}$ & $\begin{array}{l}0.0 \\
\pm 0.0 \\
(18 \mathrm{~d})\end{array}$ & & $\begin{array}{l}2.6 \\
\pm 4.0\end{array}$ & $\begin{array}{l}26.0 \\
\pm 36.2\end{array}$ & $\begin{array}{l}30.1 \\
\pm 27.3\end{array}$ & & \\
\hline AV75/CR75 & & & & & & & & & & & & $\begin{array}{r}405.1 \\
\quad(15\end{array}$ & $\begin{array}{l}+89.3 \\
\text { d) }\end{array}$ \\
\hline AV75/NORM & & & & & & & & & & & $\begin{array}{l}495.6 \\
+54.1\end{array}$ & & \\
\hline AV3/NORM & & & & $\begin{array}{l}67.6 \\
+23.5\end{array}$ & $\begin{array}{l}95.8 \\
+29.1\end{array}$ & $\begin{array}{l}161.8 \\
+55.3\end{array}$ & $\begin{array}{l}148.4 \\
+56.9\end{array}$ & $\begin{array}{l}201.6 \\
+79.3\end{array}$ & $\begin{array}{l}249.5 \\
+116.9\end{array}$ & $\begin{array}{l}249.7 \\
+101.2\end{array}$ & $\begin{array}{l}227.6 \\
28.6\end{array}$ & & \\
\hline CR3/NORM & & & & & & $\begin{array}{l}135.8 \\
+30.7\end{array}$ & $\begin{array}{l}169.0 \\
+55.4\end{array}$ & $\begin{array}{l}230.0 \\
+54.9\end{array}$ & $\begin{array}{l}229.9 \\
+56.9\end{array}$ & $\begin{array}{l}280.5 \\
+103.1\end{array}$ & $\begin{array}{l}340.0 \\
+79.9\end{array}$ & & \\
\hline SH75/NORM & & & & & & & & & & & $\begin{array}{l}610.8 \\
+71.2\end{array}$ & & \\
\hline AV3/AV75 & & & & & & & & & & & $\begin{array}{l}1.7 \\
\pm 4.5\end{array}$ & & \\
\hline CR3 + AV75/NORM & & & & & & & & & & & 350.9 & & \\
\hline CR3/AV75 & & & & & & & & & & & $\begin{array}{l} \pm 32.6 \\
132.6 \\
\pm 47.8\end{array}$ & & \\
\hline
\end{tabular}

${ }^{1}$ Mean number \pm 1 S.D. of vallate taste buds as a function of nerve operation (see Methods) and sacrifice age. Six to 11 animals per entry, except $N=4$ for entries for AV3/AV3 and AV75/AV75. AV75/CR75 animals were sacrificed at $150 \mathrm{~d}$.

regeneration of some IXth nerve axons could account for the presence of a few taste buds. After bilateral avulsion of the adult IXth nerve at $75 \mathrm{~d}$ in 4 animals, all taste buds had disappeared by $90 \mathrm{~d}$ (AV75/AV75 = 0), leaving a denervated gustatory epithelium (Fig. 1C) whose regular organization was occasionally disrupted by remnants of taste buds. Thus, in 29 of 33 neonates and adults, bilateral denervation resulted in a characteristic, rapid, and sustained absence of taste buds. At $90 \mathrm{~d}$ the vallate trench walls typically consisted of keratinizing, stratified, squamous epithelium devoid of taste buds in AV3/AV3 animals (Fig. 1A), AV3/CR3 animals (Fig. 1B), and AV75/AV75 animals (Fig. 1C), although the squamous appearance was not always pronounced (Fig. 1B). The absence of taste buds does not prove that the IXth nerve is necessary for taste bud development, since their absence in a denervated vallate papilla could be attributed to a neurotrophic requirement for the maintenance of taste buds. However, the absence of taste buds at various ages after bilateral interruption of the IXth nerves in neonates does argue that there is no early postnatal period when developing taste buds are able to mature and survive in the absence of innervation.

To determine whether innervation is necessary for the developmental formation of taste buds, we interrupted the IXth nerve using several protocols. First, we avulsed one IXth nerve and crushed the other at $3 \mathrm{~d}$ (AV3/CR3) and found a mean of 26 taste buds at $60 \mathrm{~d}$ and 30 taste buds at $90 \mathrm{~d}$. Thirty taste buds is only $5 \%$ of the 610 normally present at $90 \mathrm{~d}$, or $7.4 \%$ of the 405 taste buds present at 150 $\mathrm{d}$ after this operative protocol was carried out at $75 \mathrm{~d}$ (AV75/ CR75; Table 1). This indicates that temporary early denervation caused by crushing a IXth nerve drastically reduces the number of taste buds that form. Taste buds in AV3/CR3 animals were entirely absent from most portions of the vallate trench wall (Fig. 1B). The few present were generally clustered in patches, rather than being evenly dispersed in the epidermis. At these loci the epithelium was thicker than at nearby sites as, for example, on the opposite trench wall in Figure 1D. Totally denervated vallate epithelium in adults (Fig. 1C) was thinner than epithelia containing taste buds in AV3/CR3 animals (Fig. 1D). This difference is statistically significant for the maximal epithelial thickness (Table 2), which suggests that adequate innervation will both support taste buds and increase the thickness of the epithelium (Guth, '57).

Second, we examined the effects of unilateral interruption of the IXth nerve on taste bud development. Because of bilateral overlap of the IXth nerves, unilateral removal of the IXth nerve at $75 \mathrm{~d}$ in control animals (AV75/NORM) resulted at $90 \mathrm{~d}$ in only a $19 \%$ loss of vallate taste buds (496 \pm 54 ) relative to normal animals (NORM/NORM $=610 \pm$ 87). When unilateral interruption of the IXth nerve was carried out at $3 \mathrm{~d}$, the effects were much more profound. Numerous taste buds failed to develop by $90 \mathrm{~d}$ after one IXth nerve had been avulsed (AV3/NORM $=228$ taste buds observed) or crushed (CR3/NORM $=340$ taste buds) at $3 \mathrm{~d}$ postpartum. These values represent $54 \%$ and $31 \%$ deficits, respectively, in taste buds formed by $90 \mathrm{~d}$, compared with control animals (AV75/NORM $=496),(p<0.01$, t-test; Table 1). Following early removal of one IXth nerve (AV3/ NORM), the 228 taste buds that develop by $90 \mathrm{~d}$ appear to be structurally normal, but less densely packed together in the trench wall (Fig. 2C) than the 496 taste buds present after unilateral denervation in adults (AV75/NORM; Fig. 2D). The taste bud density of 94.8 taste buds $/ \mathrm{mm}^{2}$ in AV3/ NORM is significantly less than the taste bud density of 

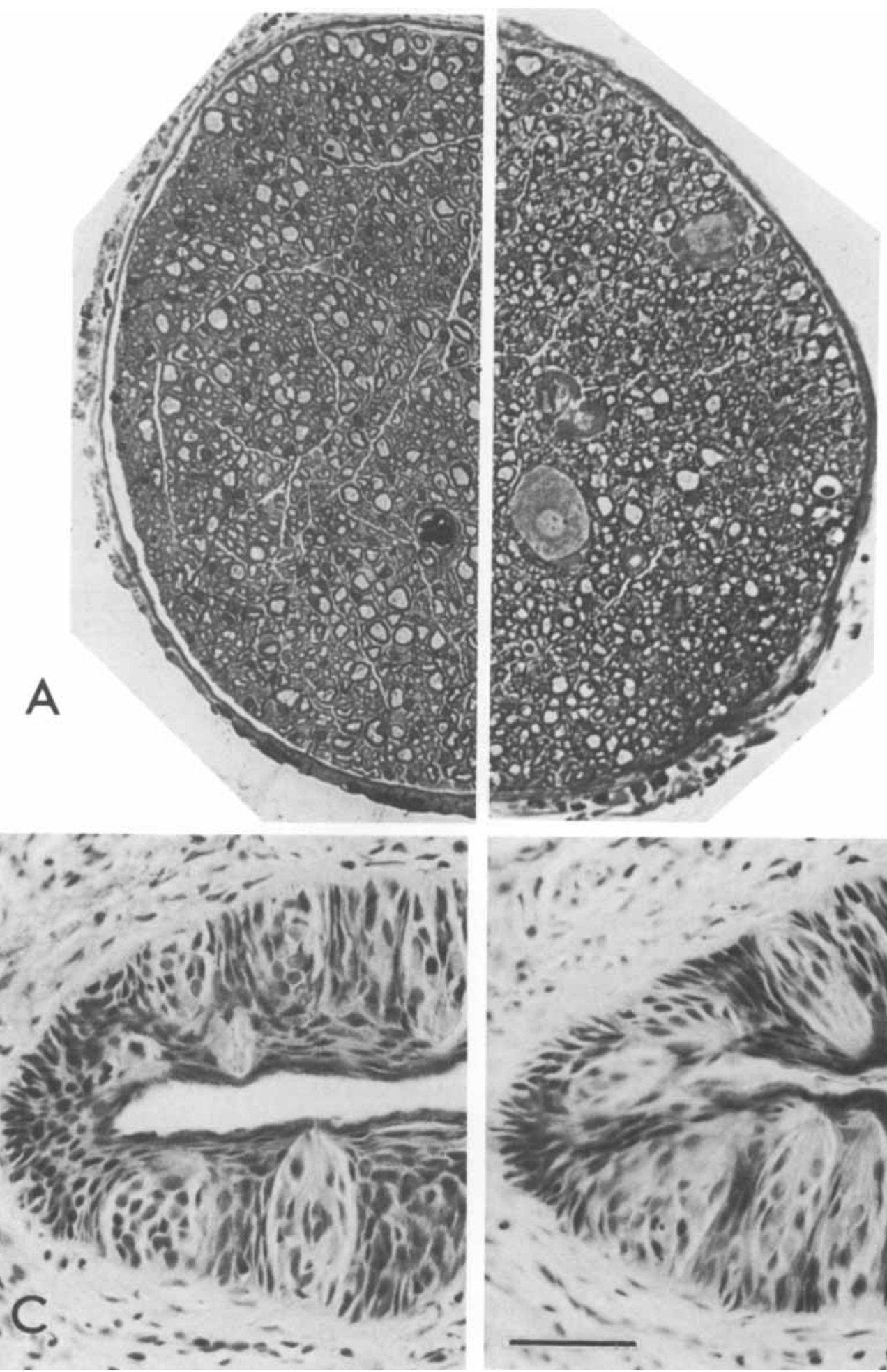

B

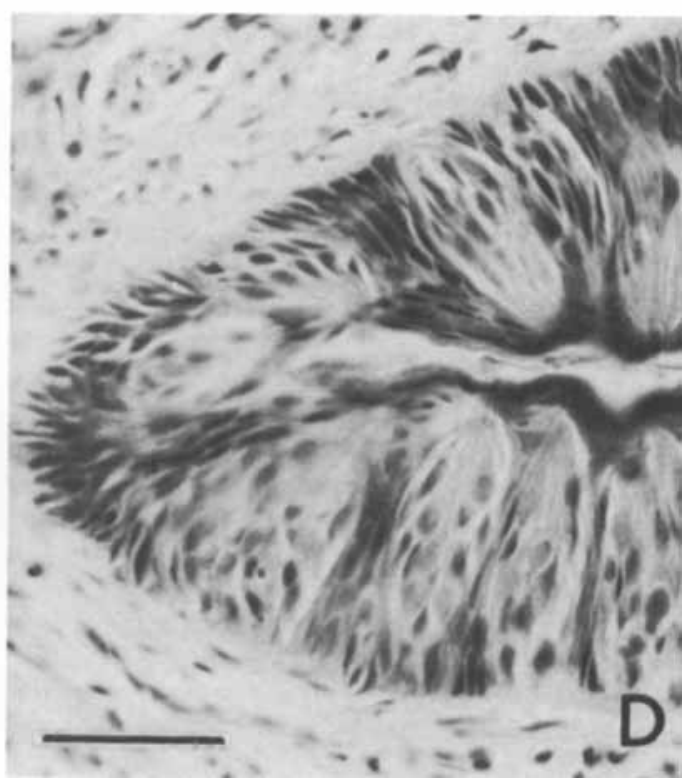

Fig. 2. One half of a cross section of the IXth nerve at $90 \mathrm{~d}$ in an AV3/NORM animal (A) and a normal animal (B). At $90 \mathrm{~d}$ there are fewer taste buds in the vallate trench of AV3/NORM animals (C) than in AV75/NORM animals (D). The scale line in D is $38 \mu \mathrm{m}$ for A and B, $50 \mu \mathrm{m}$ for C and D. 
TABLE 2. Morphometry of Rat Vallate Papilla ${ }^{1}$

\begin{tabular}{|c|c|c|c|c|c|c|c|}
\hline & Norm/Norm & AV3/Norm & CR3/Norm & AV3/CR3 & AV75/Norm & AV75/AV75 & AV75/CR75 \\
\hline $\begin{array}{l}\text { Papillary } \\
\text { length }\end{array}$ & $894 \pm 153$ & $868 \pm 92$ & $863 \pm 121.2$ & $644 \pm 58^{*}$ & $910 \pm 79$ & $694.3 \pm 101$ & $840.0 \pm 150$ \\
\hline $\begin{array}{l}\text { Papillary } \\
\text { width }\end{array}$ & $713 \pm 90$ & $611 \pm 125$ & $559 \pm 133.8$ & $580 \pm 86^{*}$ & $576 \pm 93^{*}$ & $503.0 \pm 62 *$ & $539.9 \pm 96^{*}$ \\
\hline $\begin{array}{l}\text { Papillary } \\
\text { depth }\end{array}$ & $603 \pm 133$ & $536 \pm 99$ & $709 \pm 46.6$ & $653 \pm 65$ & $756 \pm 77$ & $629.3 \pm 163$ & $648.3 \pm 68$ \\
\hline $\begin{array}{l}\text { Epidermal } \\
\text { thickness }\end{array}$ & $102 \pm 11$ & $95 \pm 16$ & $99 \pm 7.1$ & $101 \pm 23$ & $105 \pm 15$ & $64.0 \pm 12^{*}$ & $105.6 \pm 22$ \\
\hline $\begin{array}{l}\text { Trench wall } \\
\text { area }\left(\mathrm{mm}^{2}\right)\end{array}$ & $3.67 \pm 0.86$ & $2.50 \pm 0.54^{*}$ & $3.16 \pm 0.42$ & $2.52 \pm 0.41^{*}$ & $3.53 \pm 0.34$ & $2.42 \pm 0.89$ & $3.22 \pm 0.31$ \\
\hline $\begin{array}{c}\text { Taste buds } \\
\text { per } \text { mm }^{2}\end{array}$ & $215.5 \pm 73.2$ & $94.8 \pm 14.9^{*}$ & $109.7 \pm 23.8^{*}$ & $11.54 \pm 10.06^{*}$ & $148.5 \pm 20.1$ & $0.0 \pm 0.0^{*}$ & $125.8 \pm 23.3^{*}$ \\
\hline
\end{tabular}

${ }^{1}$ Vallate papilla dimensions in $\mu \mathrm{m}$, calculated trench wall surface area, and taste bud density of normal animals are compared with several groups of animals at $90 \mathrm{~d}$ (except AV75/CR75 at $150 \mathrm{~d}$ ) means \pm 1 S.D. $\mathrm{N}=6-11$ animals per protocol, except $\mathrm{N}=4$ for AV75/AV75.

${ }^{*} \mathrm{p}<0.01$, student's t-test.

148.5 taste buds $/ \mathrm{mm}^{2}$ in AV75/NORM ( $\mathrm{p}<.001$, t-test). In order to attribute the smaller number of taste buds (228) to the developmental changes in the epithelium after early partial denervation, it was necessary to show that early denervation did not cause a loss of axons in the IXth nerve contralateral to the avulsed nerve. Although such axon loss may seem to be a remote possibility, early removal of one IXth nerve might impair the remaining IXth nerve since they both innervate the vallate papilla. At $90 \mathrm{~d}$, cross sections of the IXth nerve contralateral to the IXth nerve avulsed at $3 \mathrm{~d}$ (Fig. 2A) did not differ in appearance or numbers of myelinated axons from the IXth nerve of a normal animal (Fig. 2B). In normal animals we counted $1897 \pm 273$ (mean \pm 1 S.D.) myelinated axons in 3 IXth nerves. Early IXth nerve avulsion did not alter axon numbers in the normal contralateral IXth nerve; there was a mean of $1877 \pm 274$ myelinated fibers in the IXth nerve of 3 AV3/NORM animals at $90 \mathrm{~d}$. Hence, the deficiency of taste buds in AV3/NORM animals cannot be attributed to a loss of axons in the intact contralateral nerve.

Although one IXth nerve was interrupted at $3 \mathrm{~d}$, no shortage of mature taste buds in CR3/NORM and AV3/NORM animals is apparent until after $15 \mathrm{~d}$ (Fig. 3). Between 15 and $45 \mathrm{~d}$, CR3/NORM and AV3/NORM animals incur simi-

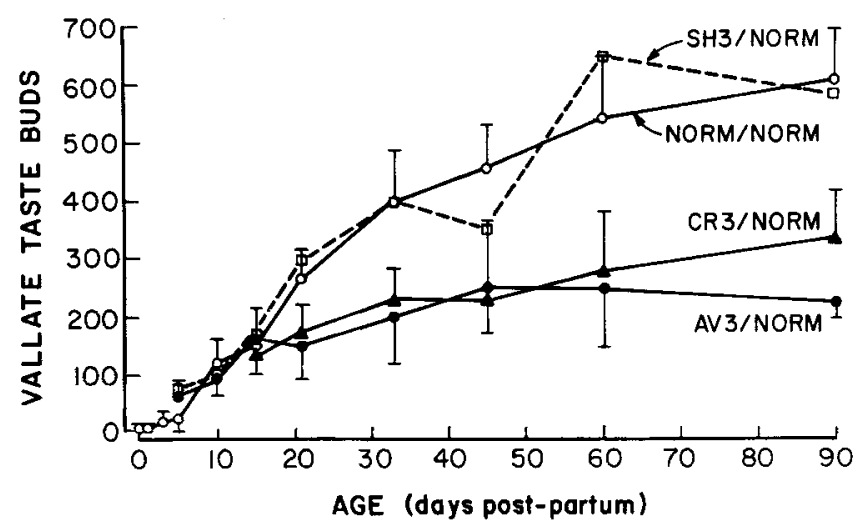

Fig. 3. The total number of vallate taste buds is shown as a function of animal age. Normal (NORM/NORM O-), unilateral sham IXth nerveoperated at $3 \mathrm{~d}$ (SH3/NORM $\square---$ ), unilateral avulsion of the IXth nerve at $3 \mathrm{~d}$ (AV3/NORM - - ), unilateral crush of the IXth nerve at $3 \mathrm{~d}$ (CR3/ NORM $\triangle \longrightarrow-$. lar deficits in numbers of taste buds. For AV3/NORM animals there is little increase in numbers of taste buds between $33 \mathrm{~d}(202 \pm 79$ taste buds) and $90 \mathrm{~d}(228 \pm 29)$. The regeneration of crushed axons (vide infra) in CR3/ NORM animals produced additional taste buds that matured after $45 \mathrm{~d}$, leading to a total of $340 \pm 80$ taste buds by $90 \mathrm{~d}$, which is significantly greater than the $228 \pm 29$ taste buds in AV3/NORM animals ( $p<0.01$, t-test). When the number of taste buds formed is plotted against $\log _{10}$ age, the resulting linear functions for AV3/NORM or CR3/ NORM animals differ significantly in slope and $y$ intercept from both normal and sham nerve-operated animals ( $p<$ 0.001).

We controlled for the possibility that the general operative procedures might have disrupted taste bud development. At $90 \mathrm{~d}$, the number of taste buds in animals that were sham nerve-operated at 3 or $75 \mathrm{~d}$ (SH3/NORM $=586$ $\pm 91 ; \mathrm{SH} 75 / \mathrm{NORM}=611 \pm 71$ ) was not significantly different from those of normal animals (NORM/NORM = $610 \pm 87$ ). However, between 5 and $15 \mathrm{~d}$ the taste bud values for SH3/NORM animals closely approximated those of the AV3/NORM animals, and both groups had 3 times as many taste buds as NORM/NORM animals at $5 \mathrm{~d}(\mathrm{p}<$ 0.01 , t-test). Thus, operations at $3 \mathrm{~d}$, including sham nerve interruption, seemed to temporarily hasten taste bud development and maturation.

The AV3/AV75 control group best evaluated whether avulsion of the right IXth nerve at $3 \mathrm{~d}$ was permanently effective because by $75 \mathrm{~d}$, successfully regenerated axons of the right IXth nerve would have had $200+$ taste buds available to innervate. However, after the normal left IXth nerve was removed at $75 \mathrm{~d}, 6$ of 7 rats had no vallate taste buds at $90 \mathrm{~d}$ (Table 1). This argues for the success of early avulsion in permanently preventing reinnervation.

Last, we wished to investigate the interactions between normal and regenerating axons that caused CR3/NORM animals to develop 112 more taste buds than AV3/NORM animals by $90 \mathrm{~d}(340-228=112)$. Certainly, the axons returning from the crushed nerve must contribute to the formation of these additional taste buds, but the normal nerve must also contribute since a crushed nerve acting alone induced only 30 taste buds (AV3/CR3 $=30$ ). These results suggest that the normal nerve may have innervated some epithelial cells too sparsely to produce taste buds unless supplemented by axons of the regenerated IXth nerve. To test the proposition that the regenerating axons of CR3/NORM animals produced taste buds from cells also 
innervated by the normal nerve, we removed the CR3 nerve at $75 \mathrm{~d}$. At $90 \mathrm{~d}$ it was evident that the normal nerve trophically maintained all taste buds (CR3+ AV75/NORM $=351$ ), in agreement with the hypothesis that the 112 taste buds were formed jointly by the CR3 and normal axons.

A second measure of the number of taste buds added by the CR3 nerve is given by the numerical difference between those taste buds induced by one normal nerve acting alone $(\mathrm{AV} 3 / \mathrm{NORM}=228)$ and those taste buds maintained by one normal nerve after the normal and CR3 nerves had both been present during development [(CR3+AV75/ NORM $)-($ AV3/NORM $)=351-228=123$ ]. Averaging 123 with 112 gives a mean estimate of 118 taste buds formed by the CR3 nerve. These comparisons are summarized in Figure 4. The number of taste buds maintained at $90 \mathrm{~d}$ by axons of the crushed nerve is given directly by the retention of $133 \pm 48$ vallate taste buds following avulsion of the normal IXth nerve at 75 d (CR3/AV75; Fig. 4). Evidently, axons of the CR3 nerve formed an average of 118 additional taste buds, yet maintained few, if any, of the 228 taste buds formed by 1 normal nerve.

Some dimensions of the vallate papilla were affected by unilateral interruption of the IXth nerve (Table 2). With bilaterally interrupted nerves, there was a $20-30 \%$ reduction in papilla width, relative to normal values at $90 \mathrm{~d}$, and in the AV3/CR3 group a $28 \%$ reduction in papilla length ( $p$ $<0.01$ ). The smaller papilla of AV3/CR3 animals may not be due to reduced papilla growth since the same operation at $75 \mathrm{~d}$ also reduced papilla size (Table 2). Thinning of the maximum thickness of the trench wall epithelium occurred in AV75/AV75 animals $(\mathrm{p}<0.01$ ). Avulsion of one IXth nerve at $3 \mathrm{~d}$ led to a reduction in surface area of the epithelium $(p<0.01)$. The density of taste buds, per unit area of epidermis, was markedly reduced following interruption of the nerve supply in AV3/NORM, CR3/NORM, AV3/CR3, and AV75/CR75 animals ( $p<0.01$ ). Hence, it is unlikely that overcrowding of buds, caused by a failure of the papilla to grow, was responsible for the shortages of taste buds observed after nerve interruption.

When we held constant the number of IXth nerve axons present at $90 \mathrm{~d}$, the number of taste buds maintained was a function of the history of innervation. This is illustrated in the comparison of the following three groups, which had the same final number of normal axons but more than a twofold difference in taste buds: AV3/NORM animals, 228 taste buds; CR3 + AV75/NORM animals, 351 taste buds, and AV75/NORM animals, 496 taste buds. Crushed nerves suffered a loss of some axons: CR75 nerves had $1587 \pm 495$ myelinated axons $(\mathrm{N}=3)$, CR3 nerves had $835 \pm 252$ myelinated axons $(\mathrm{N}=3)$.

\section{DISCUSSION}

The possibility of an inductive role for taste axons, in addition to their trophic or maintenance role, has been

AV3/CR3
CR3/NORM
AV3/NORM
CR3 + AV75/NORM
CR3/AV75

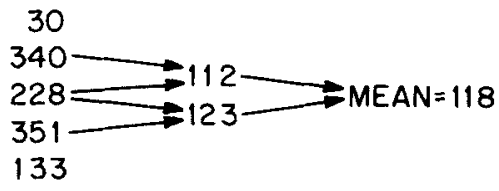

Fig. 4. The number of taste buds associated with crush or avulsion of the nerve is shown for 5 protocols. Differences in the number of taste buds between adjacent pairs and a mean difference of 118 are also shown. raised in studies of taste bud structure (Hermann, 1884; Torrey, '40; El-Eishi and State, '74; State and Bowden, '74) and ultrastructure (Farbman, '65, '67). Our experiments suggest that taste bud development requires the presence of axons in the gustatory epithelium. Fewer taste buds form after unilateral avulsion at $3 \mathrm{~d}(\mathrm{AV} 3 / \mathrm{NORM}=228)$ than remain after unilateral avulsion at $75 \mathrm{~d}$ in either the AV75/ NORM (496) or CR3+AV75/NORM (351) groups. All 3 groups have equal numbers of myelinated axons at $90 \mathrm{~d}$, but have substantially different numbers of taste buds owing to the timing of denervation.

One might anticipate that the number of neurotrophically maintained taste buds would be related to the number of axons present. Crushing the IXth nerve at $75 \mathrm{~d}$ produced an $18 \%$ loss of taste buds and a $16 \%$ reduction in the number of myelinated axons (405 taste buds and 1,587 myelinated axons in AV75/CR75 vs 496 taste buds and 1,877 axons in AV75/NORM). AV3/CR3 animals formed only $7 \%$ of the taste buds that are maintained following the same operation in adults ( 30 vs 405 in AV75/CR75). This 93\% shortage of taste buds was associated with a $47 \%$ reduction in the number of myelinated axons (AV3/CR3 $=835$ myelinated axons). Hence, in AV3/CR3 animals either an early virtual absence of neural induction or a sustained shortage of axons for trophic support might account for the shortage of buds in adults. The AV3/NORM protocol was able to distinguish between early neural induction and neurotrophic maintenance. In these animals, only $37 \%$ of the vallate taste buds developed, whereas $81 \%$ were predicted from unilateral IXth nerve avulsions in adults (AV3/NORM = 228 vs $\mathrm{AV75} / \mathrm{NORM}=496$ ). This mean shortfall of 268 taste buds cannot be attributed to reduced taste bud maintenance owing to axon loss, since in each protocol one normal IXth nerve was present, and we determined that removal of a IXth nerve had no effect on the number of axons present in the normal contralateral IXth nerve or in its appearance (Fig. 2A,B). Additionally, since animals with $3 \mathrm{~d}$ sham nerve-removal operations (SH3/NORM) had normal numbers of taste buds at $90 \mathrm{~d}$, the significant taste bud deficits associated with nerve interruption at $3 \mathrm{~d}$ could not have been a result of general surgical procedures. In normal animals the right and left IXth nerves act synergistically to support 2.7 times as many vallate taste buds as one nerve does when it acts alone in AV3/NORM animals $[610$ $-(228 \times 2)=154$ extra tast buds]. In AV3/NORM animals the shortfall of taste buds at all ages after $15 \mathrm{~d}$ (Fig. 3), probably represents a failure of numerous taste buds to develop, rather than a failure to maintain taste buds, since at the outset at $3 \mathrm{~d}$ there were fewer than 20 vallate taste buds, and we found no evidence of degeneration to suggest the $150+$ taste buds that were missing by $90 \mathrm{~d}$ had developed and matured after $3 \mathrm{~d}$ but subsequently had degenerated. We conclude that it is neural synergism in the development of new taste buds, rather than in the maintenance of existing taste buds, that is responsible for the 154 extra taste buds present in normal animals. Many vallate taste buds must be neurally induced.

The time course of taste bud proliferation warrants further consideration. At $3 \mathrm{~d}$ the number of axons cannot be the rate-limiting factor in taste bud development or losses would occur soon after unilateral nerve avulsion, as they do in the AV3/AV3 group in which taste buds degenerate by $10 \mathrm{~d}$ (Table 1 ). Unilateral interruption of the IXth nerve at $3 \mathrm{~d}$ (CR3/NORM, AV3/NORM) did not slow the rate of taste bud maturation until after $15 \mathrm{~d}$ (Fig. 1). This suggests 
that at $3 \mathrm{~d}$ the developing and mature taste buds are bilaterally innervated, allowing one nerve to sustain taste bud development temporarily. By $21 \mathrm{~d}$ a single IXth nerve can no longer maintain the normal rate of taste bud proliferation, and a shortage of taste buds occurs.

In normal animals the number of vallate taste buds continues to increase gradually for 2-3 mo (Fig. 3). As discussed elsewhere (Hosley and Oakley, '87), this may reflect density-dependent control in which taste bud maturation occurs only in growing regions of the papilla. In AV3/CR3 and CR3/NORM animals most of the taste buds that formed in response to regenerating axons of nerves crushed at $3 \mathrm{~d}$ were added between 45 and $90 \mathrm{~d}$. Because the density of the taste buds was substantially reduced following IXth nerve crush at $3 \mathrm{~d}$, overcrowding is not likely to have been responsible for this slow maturation of taste buds. In contrast, in adult rats crushed IXth nerves reformed vallate taste buds within 4 weeks (State, '77). The Schwann cell sheaths in adults probably guide regenerating axon to prior sites of peripheral targets. CR3 axons may have less effective pathway guidance. They grow in an environment altered by papilla growth, and they may encounter areas not previously innervated that, therefore, lack old glial tracks for guidance.

There were no direct observations on the manner by which the additional 118 taste buds were formed by the regenerated axons in CR3/NORM animals. It seems unlikely that these taste buds arose after $45 \mathrm{~d}$ by the splitting or division of existing taste buds innervated by the normal nerve, for this would predict that the CR3 axons would not only innervate the additional taste buds they generated, but the parent taste buds as well. However, the CR3 nerve only maintained the added taste buds, whereas the normal nerve maintained all taste buds.

With a lifespan of only 9-10 d, adult taste cells represent a renewing cell population derived from stem cells (Beidler and Smallman, '65; Conger and Wells, '69; Farbman, '80). Stem cells are those cells that, when innervated, give rise to the differentiated cells of the taste bud. After nerve regeneration in adults, taste buds are reconstituted from differentiated daughters of the stem cells. In adults, one IXth nerve will maintain 496 taste buds, yet in development will induce only 228 taste buds de novo. Adult taste nerves supply a trophic agent(s) (Sloan et al., '83), which may be more abundant or a qualitative improvement on the inductive agent(s) in taste bud development. Alternatively, the neural induction of stem cells from progenitor cells during development may make greater quantitative demands on a fixed supply of a trophic agent(s) than does the maintenance of taste buds from adult stem cells.

In a simple model of development, progenitor cells give rise to stem cells that in turn give rise to the intragemmal cells of the taste bud (Fig. 5). In this model, taste axons induce stem cells from progenitor cells in development, whereas they trophically maintain taste buds from stem cells in adults and reform taste buds from stem cells in regeneration.

\section{SUMMARY}

Vallate taste buds in the rat reach stable numbers by 90 $\mathrm{d}$; more than $80 \%$ of the 610 taste buds are bilaterally innervated by the IXth nerve.

The first vallate taste buds to develop are probably bilaterally innervated since unilateral denervation at $3 \mathrm{~d}$ does

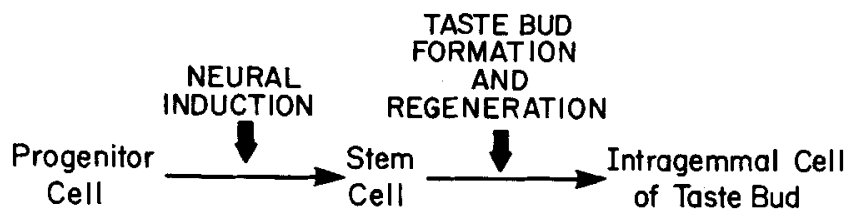

Fig. 5. A model of the role of the nerve in mammalian taste bud development.

not reduce the number of mature taste buds for about 2 weeks.

Early or late bilateral removal of the IXth nerve causes an absence of vallate taste buds.

Sham nerve removal at 3 or $75 \mathrm{~d}$ does not change the number of taste buds that are present at $90 \mathrm{~d}$, although the general operative procedures at $3 \mathrm{~d}$ may briefly accelerate taste bud maturation.

The $63 \%$ reduction in the number of vallate taste buds that develop after early unilateral removal of the IXth nerve suggests that taste buds may be neurally induced.

The neural induction of taste buds is also supported by 2 examples of synergism. One, the right and left IXth nerves do not compete for targets, but rather, by acting synergistically, jointly produce over 150 more taste buds than arise by the sum of their independent actions. Two, axons crushed at $3 \mathrm{~d}$ lead to the formation of almost 4 times as many taste buds in the presence of the normal contralateral IXth nerve as in its early absence.

Regenerating axons in CR3/NORM animals lead to the formation of about 118 additional taste buds in conjunction with normal axons, but innervate few of the 228 taste buds that arise in the presence of 1 normal nerve. The 118 additional taste buds probably do not arise by the division of existing taste buds.

In taste bud development, we propose, as a minimal sequence, that progenitor cells are neurally induced to stem cells that give rise to daughters, which differentiate into the cells of the taste bud.

\section{ACKNOWLEDGMENTS}

We are grateful for the assistance of B.L. Bower, L. Morton, and K. Wilson. We are also thankful for the technical assistance provided by the laboratories of D.J. Chiego, C.F. Cox, and F.F. Ebner. Part of this work is taken from a dissertation submitted by M.A.H. in partial fulfillment of the Ph.D. requirements of the Rackham School of Graduate Studies at the University of Michigan. This research was supported in part by block grants from the University of Michigan Rackham School of Graduate Studies and NIH grant NS-07072.

\section{LITERATURE CITED}

Beidler, L.M., and R.L. Smallman (1965) Renewal of cells within taste buds. J. Cell Biol. 27:263-272.

Berthold, C.H., and T. Carlstedt (1973) Fixation and numerical estimation of myelinated nerve fibers during initial myelination in the cat. Neurobiology 3:1-18,

Conger, A.D., and M.A. Wells (1969) Radiation and aging effect on taste structure and function. Rad. Res. 37:31-49.

Dowdy, S., and S. Wearden (1983) Statistics for Research. New York: John Wiley and Sons. 
El-Eishi, H.I, and F.A. State (1984) The role of the nerve in the formation and maintenance of taste buds. Acta Anat. 89:599-609.

Farbman, A.I. (1965) Electron microscope study of the developing taste bud in rat fungiform papilla. Dev. Biol. 11:110-135.

Farbman, A.I. (1967) A particle-membrane complex in developing rat taste buds. J. Ultrasruct. Res. 19:514-521.

Farbman, A.I. (1972) Differentiation of taste buds in organ culture. J. Cell Biol. 52:489-493.

Farbman, A.I. (1980) Renewal of taste bud cells in rat circumvallate papillae. Cell. Tiss. Kinet. 13:349--357.

Guth, L. (1957) The effects of glossopharyngeal nerve transection on the circumvallate pappila of the rat. Anat. Rec. 128:715-731.

Guth, L. (1963) Histological changes following partial denervation of the circumvallate papilla of the rat. Exp. Neurol. 8:336-349.

Harrison, R.G. (1904) Experimentelle Untersuchungen über die Entwick lung der Sinnesorgane der Seitenlinie bei den Amphibien. Arch. f. mikr. Anat. 63:35-149.

Hermann, F. (1884) Beitrag zur Entwicklungsgeschiste des Geschmacksorgans beim Kaninchen. Arch. f. mikr. Anat. 24:216-229.

Hosley, M.A., and B. Oakley (1987) Development of the vallate papilla and taste buds in rats. Anat. Rec. (in press).

Hughes, S.E., H.E. Sloan, L.B. Jones, and B. Oakley (1983) Colchicine reduces myelin thickess and axoplasm volume. Neurosci. Lett. 37:181186.

Oakley, B. (1974) On the specification of taste neurons in the rat tongue Brain Res. 75:85-96.

Rogers, S.L. (1981) Muscle spindle formation and differentiation in regen erating rat muscle grafts. Dev. Biol. 94:265-283.

Rogers, S.L., and B.M. Carlson (1981) A quantitative assessment of muscle spindle formation in reinnervated and non-reinnervated grafts of the rat extensor digitorum longus muscle. Neurosci. 6:87-94.

Schiaffino, S., and S. Pierobon (1976) Morphogensis of rat muscle spindles after nerve lesion during early postnatal development. J. Neurocyt. $5: 319-336$.
Sloan, H.E., S.E. Hughes, and B. Oakley (1983) Chronic impairment of axonal transport eliminates taste responses and taste buds. J. Neurosci. 3:117-123.

Spurlock, B.O., M.S. Skinner, and A.A. Kattine (1966) A simple rapid method for staining epoxy-embedded specimens for light microscopy with the polychromatic stain Paragon-1301. Am. J. Clin. Path. 46:252258.

State, F.A. (1977) Histological changes following unilateral reinnervation of the circumvallate papilla of rat. Acta. Anat. 98:343-352.

State, F.A., and R.E.M. Bowden (1974) Innervation and cholinesterase activ. ity of the developing taste buds in the circumvallate papilla of the mouse. J. Anat. 118:211-221.

Torrey, T.W. (1940) The influence of nerve fibers upon taste buds during embryonic development. Proc. Nat. Acad. Sci. 26:627-634.

Werner, J.K. (1973) Duration of normal innervation required for complete differentiation of muscle spindles in newborn rats. Exp. Neurol. 41:214217.

Whiteside, B. (1927) Nerve overlap in the gustatory apparatus of the rat. J. Comp. Neurol. 44:363-377.

Winkelman, R.K. (1960) Nerve Endings in Normal and Pathologic Skin. Springfield: C.C. Thomas, pp. 159-161.

Zalewski, A.A. (1974) Trophic functions of neurons in transplanted neonatal ganglia. Exp. Neurol. 45:189-193.

Zelena, J. (1957) The morphogenetic influence of innervation on the ontogenetic development of muscle spindles. J. Embryol. Exp. Morph. 5:283292.

Zelena, J. (1980) Rapid degeneration of developing rat Pacinian corpuscies after denervation. Brain Res. 187:97-111.

Zelena, J., and T. Soukup (1973) Development of muscle spindles deprived of fusimotor innervation. Z. Zellforsch. 144:435-452.

Zelena, J., M. Sobotkova, and H. Zelena (1978) Age modulated dependence of Pacinian corpuscles upon their sensory innervation. Physiol. Bohem. 27:437-443. 